\title{
Evaluation of Antioxidant Activity of Some Medicinal plants and their Combination
}

\author{
Tanuj Joshi*, Vijay Juyal
}

Tanuj Joshi*, Vijay Juyal

Department of Pharmaceutical Sciences, Bhimtal, Pin: 263136, Kumaun University (Nainital), INDIA.

\section{Correspondence}

Tanuj Joshi

Department of Pharmaceutical Sciences Bhimtal, Pin: 263136, Kumaun University (Nainital), INDIA

E-mail: joshitanuj18@gmail.com

History

- Submission Date: 26-10-2020;

- Review completed: 23-12-2020;

- Accepted Date: 01-02-2021.

DOI : 10.5530/pj.2021.13.75

Article Available online

http://www.phcogj.com/v13/i2

\section{Copyright}

(C) 2021 Phcogj.Com. This is an openaccess article distributed under the terms of the Creative Commons Attribution 4.0 International license.

\begin{abstract}
Introduction: Oxidative Stress leads to several complications within the human body. It is the reason behind the generation of several diseases. Free radicals if generated in excess amount can damage the body to a great extent. Finding newer and potent medicinal plants that can fight oxidative stress can be useful in combating the harmful effects of free radicals. Methods: In the current study ethanolic extract of Ocimum kilimandscharicum, Thymus serpyllum, Spilanthes acmella and their combination in equal ratio were used for their ability to counter oxidative stress. The plants were collected from the district of Pithoragarh, Uttarakhand and extracted by soxhlet's apparataus using absolute ethanol (99.9\%). The extracts were then dried and used for the study. Result: It was seen that highest absorbance was shown by ascorbic acid at the lowest as well as the highest concentration in the reducing power assay. Also, the combination of the extracts showed the highest absorbance among all the extracts at both the lowest and highest concentration. Conclusion: A higher absorbance indicates a better antioxidant potential. The best effect was shown by the combined extract among all the extracts.

Key words: Oxidative stress, Reducing power, Flavonoids, Phenols.
\end{abstract}

\section{INTRODUCTION}

Oxidative damage and antioxidants are assuming great interest in today's modern world. Cancer, cardiovascular diseases and other types of diseases may be due to the result of free radicals. ${ }^{1}$ With newer insights into the fact that oxidative species can lead to a number of health problems and complications, finding treatment of oxidative damage and oxidative stress is acquiring greater significance. Phytochemicals obtained from plants are gaining popularity day by day in countering harmful effects of oxidative species and diseases associated with oxidative damage. Various fruits, vegetables and medicinal plants contain numerous phytochemicals. ${ }^{1,2}$ Many phytochemicals have been isolated and tested for their therapeutic potentials but many phytochemicals are still there which need to be discovered in future. Phytochemicals have a wide variety of beneficial effects. They possess antioxidant activity, enhance immunity, reduce aggregation of platelets, influence the activity of hormones and have anticancer effects. Besides the above mentioned pharmacological activities, they produce numerous other actions as well. ${ }^{3}$ Various phytochemicals have various pharmacological activities. Cellulose, lignins, gums and pectins bind toxins. Alkaloids, phenolic compounds and terpenoids have antimicrobial potential. Ascorbic acid, carotenoids, phenols and flavonoids have potent antioxidant capabilities. Antitumor activities have been shown by flavonoids, phenols etc. Carotenoids, tocopherols, phenols, flavonoids etc function as detoxifying agents. ${ }^{2}$ Phenols and flavonoids are some plant constituents that have gained popularity over the years for treatment of oxidative stress. Many medicinal plants contain different phenolic compounds and flavonoids that help in a variety of diseases. In many experiments flavonoids and phenols have proved their potential in protecting the body against harmful effects of free radicals. ${ }^{1,2}$ They protect proteins, lipids and deoxyribonucleic acid (DNA) against harmful effect of the free radicals. Also phenolic compounds and flavonoids may assist the natural antioxidant defence system of the body and help to fight oxidative damage within the body. ${ }^{4}$ In the present study three medicinal plants Ocimum kilimandscharicum (OCM), Thymus serpyllum (THY), Spilanthes acmella (SPL) and their combination in 1:1:1 ratio (COMB) were assessed for their phytochemical constituents and antioxidant activity.

\section{PLANT COLLECTION AND IDENTI- FICATION}

Aerial parts of Ocimum kilimandscharicum, Thymus serpyllum and Spilanthes acmella were collected from the herbal gardens of Defence Institute of Bioenergy Research, Pithoragarh. The plant samples were preliminarily identified by ICAR-National Bureau of Plant Genetic Resources, Regional station, Niglat, Bhowali, Uttarakhand. The plant samples were further sent to Botanical Survey of India, Northern Botanical Survey of India for final authentication.

\section{Preparation of the extract}

After collection, the aerial parts of the above mentioned plants were dried. After drying the aerial parts were powdered and extracted with absolute ethanol (99.9\%). Soxhlet's assembly was used for the extraction. The extract so obtained was then dried using rotatory vaccum flash evaporator. ${ }^{5}$ 


\section{Experimental procedure}

\section{Phytochemical screening of the extracts}

The extracts of Ocimum kilimandscharicum (OCM), Thymus serpyllum (THY) and Spilanthes acmella (SPL) were individually subjected to phytochemical screening. Also, the extracts of the above mentioned plants were combined in equal ratio $(1: 1: 1)$ and subjected to phytochemical screening according to procedures mentioned in literature. ${ }^{6,7}$

\section{In-vitro antioxidant activity using reducing power assay}

Seven $\log$ concentrations $(0.0001-50 \mu \mathrm{g} / \mathrm{ml})$ of the extracts namely OCM, THY, SPL and COMB (combination of Ocimum kilimandscharicum, Thymus serpyllum and Spilanthes acmella in 1:1:1 ratio) in $1 \mathrm{ml}$ of water were mixed with phosphate buffer $(2.5 \mathrm{ml}, 0.2$ $\mathrm{mol}, \mathrm{pH} 6.6)$ and $1 \%$ potassium ferricyanide $(2.5 \mathrm{ml})$. The mixture was incubated at $50^{\circ} \mathrm{C}$ for $20 \mathrm{~min}$. Aliquots of trichloroacetic acid $(2.5 \mathrm{ml}$,
$10 \%)$ were added to the mixture. Centrifuged the mixture at $3000 \times \mathrm{g}$ for $10 \mathrm{~min}$. Upper layer of solution $(2.5 \mathrm{ml})$ was mixed with distilled water $(2.5 \mathrm{ml})$ and freshly prepared ferric chloride solution $(0.5 \mathrm{ml}$, $0.1 \%$ ). The absorbance was measured at $700 \mathrm{~nm}$ (BMG FLUOSTAR, GERMANY). ${ }^{8-10}$

\section{RESULTS}

\section{Phytochemical screening of the extracts}

The individual extracts as well as the combined extracts were subjected to preliminary phytochemical screening tests using various methods. The results are given in the Table 1.

\section{Reducing power assay}

Individual extracts, combined extract and ascorbic acid showed different absorbance at different concentrations. A higher absorbance indicates higher reducing power due to formation of reduced intermediate (Table 2).

Table 1: Phytochemical screening of OCM, SPL, THY and COMB.

\begin{tabular}{|c|c|c|c|c|c|}
\hline \multirow[t]{2}{*}{ PHYTOCEMICAL TESTS } & \multirow[t]{2}{*}{ OBSERVATIONS } & \multirow{2}{*}{$\begin{array}{c}\text { RESULTS } \\
\text { OCM }\end{array}$} & \multirow{2}{*}{$\begin{array}{c}\text { RESULTS } \\
\text { THY }\end{array}$} & \multirow{2}{*}{$\begin{array}{l}\text { RESULTS } \\
\text { SPL }\end{array}$} & \multirow{2}{*}{$\begin{array}{l}\text { RESULTS } \\
\text { COMB }\end{array}$} \\
\hline & & & & & \\
\hline \multicolumn{6}{|l|}{ Alkaloids } \\
\hline (a) Dragendorff's test & Orange brown precipitate & Absent & Absent & Absent & Absent \\
\hline (b) Mayer's test & Precipitate formation & Absent & Absent & Absent & Absent \\
\hline (c) Hager's test & Yellow precipitate & Absent & Absent & Absent & Absent \\
\hline (d) Wagner's test & Reddish brown precipitate & Absent & Absent & Absent & Absent \\
\hline (e) Tannic acid test & Buff colored precipitate & Absent & Absent & Absent & Absent \\
\hline \multicolumn{6}{|l|}{ Proteins } \\
\hline (a) Biuret test (General Test) & Violet or Pink color & Absent & Absent & Absent & Absent \\
\hline (b) Millon's test (for protein's) & $\begin{array}{l}\text { White precipitate. Warm } \\
\text { precipitate, it turns brick red } \\
\text { or the precipitate dissolves } \\
\text { giving red colored solution }\end{array}$ & Absent & Absent & Absent & Absent \\
\hline \multicolumn{6}{|l|}{ Amino acids } \\
\hline $\begin{array}{l}\text { (a) Ninhydrin test (General } \\
\text { test) }\end{array}$ & Purple or bluish color & Absent & Absent & Absent & Absent \\
\hline \multicolumn{6}{|l|}{ Carbohydrates } \\
\hline (a) Molisch's test (General test) & $\begin{array}{l}\text { Violet ring is formed at the } \\
\text { junction of two liquids }\end{array}$ & Present & Present & Present & Present \\
\hline \multicolumn{6}{|l|}{ Saponin Glycosides } \\
\hline (a) Foam test & $\begin{array}{l}\text { Persistent stable foam was } \\
\text { observed on shaking the } \\
\text { extract with water }\end{array}$ & Present & Present & Present & Present \\
\hline \multicolumn{6}{|l|}{ Flavonoids } \\
\hline $\begin{array}{l}\text { (a) Sulphuric Acid test }(66 \% \\
\text { or } 80 \%)\end{array}$ & $\begin{array}{l}\text { Deep yellow solution } \\
\text { (flavones and flavonols) }\end{array}$ & Present & Present & Present & Present \\
\hline $\begin{array}{l}\text { (b) On addition of lead } \\
\text { acetate to residue }\end{array}$ & Yellow colored precipitate & Present & Present & Present & Present \\
\hline $\begin{array}{l}\text { (c) Addition of increasing } \\
\text { amount of sodium hydroxide } \\
\text { to the residue }\end{array}$ & $\begin{array}{l}\text { Yellow coloration, which } \\
\text { decolorizes after addition } \\
\text { of acid }\end{array}$ & Present & Present & Present & Present \\
\hline \multicolumn{6}{|l|}{ Phenols and Tannins } \\
\hline (a) $5 \% \mathrm{FeCl}_{3}$ solution & Deep blue-black color & Present & Present & Present & Present \\
\hline (b) Lead acetate solution & White precipitate & Present & Present & Present & Present \\
\hline $\begin{array}{l}\text { (c) Dilute Potassium } \\
\text { permanganate solution }\end{array}$ & Decoloration & Present & Present & Present & Present \\
\hline
\end{tabular}


Table 2: Absorbance values at various concentrations of different extracts and ascorbic acid in reducing power assay.

\begin{tabular}{|c|c|c|c|c|c|c|c|}
\hline & \multicolumn{7}{|c|}{ Absorbance at various concentrations } \\
\hline & $0.0001 \mu \mathrm{g} / \mathrm{ml}$ & $0.001 \mu \mathrm{g} / \mathrm{ml}$ & $0.01 \mu \mathrm{g} / \mathrm{ml}$ & $\begin{array}{c}0.1 \\
\mu \mathrm{g} / \mathrm{ml}\end{array}$ & $\begin{array}{c}1 \\
\mu \mathrm{g} / \mathrm{ml}\end{array}$ & $\begin{array}{c}10 \\
\mu \mathrm{g} / \mathrm{ml}\end{array}$ & $\begin{array}{c}50 \\
\mu \mathrm{g} / \mathrm{ml}\end{array}$ \\
\hline OCM & 0.21 & 0.24 & 0.23 & 0.9 & 0.95 & 1.41 & 1.64 \\
\hline THY & 0.22 & 0.21 & 0.27 & 0.33 & 0.32 & 0.41 & 0.52 \\
\hline SPL & 0.13 & 0.15 & 0.17 & 0.25 & 0.28 & 0.34 & 0.47 \\
\hline COMB & 0.24 & 0.22 & 0.28 & 1.57 & 1.64 & 1.72 & 1.82 \\
\hline ASCORBIC ACID & 0.42 & 0.97 & 1.35 & 1.66 & 2.18 & 2.22 & 2.71 \\
\hline
\end{tabular}

\section{DISCUSSION}

In the present study it was seen that at the lowest concentration $(0.0001 \mu \mathrm{g} / \mathrm{ml})$ the highest absorbance was shown by ascorbic acid and lowest absorbance was shown by SPL. At the highest concentration $(50 \mu \mathrm{g} / \mathrm{ml})$ highest absorbance was shown by ascorbic acid and lowest absorbance was shown by SPL. Highest absorbance was shown by THY in lowest concentration $(0.0001 \mu \mathrm{g} / \mathrm{ml})$ and highest absorbance was shown by OCM at the highest concentration $(50 \mu \mathrm{g} / \mathrm{ml})$ among the individual extracts. Among all the extracts COMB showed better effect than the individual extracts in the reducing power assay at both the lowest and highest concentrations (Table 2 ). In reducing power assay antioxidants provide a beneficial effect by breaking the free radical chain by donating a hydrogen atom. ${ }^{11}$ In this assay antioxidants act as reductants and reduce $\mathrm{Fe}^{3+} /$ ferricyanide complex to ferrous form. The absorbance of ferrous ions can be measured at $700 \mathrm{~nm}$. In this assay increase in absorbance is an indicator of increasing reductive ability. ${ }^{12}$. Phytochemical screening has revealed the presence of antioxidant phytochemicals like, phenols and flavonoids in the extracts of the OCM, THY, SPL and COMB (Table 1). As has been discussed in the introduction that phenols and flavonoids have potent antioxidant activity, thus the presence of these phytochemicals might be responsible for the antioxidant activity of these extracts.

\section{CONCLUSION}

Diseases due to oxidative stress are posing a significant burden on humans. Newer research is being carried out by scientists to study the impact of free radicals in causing diseases. Medicinal plants have the potential to become frontline medicines in the treatment of oxidative stress. Also, these plants have the advantage that they are economical and a safe alternative to allopathic drugs and synthetic antioxidant formulations. Newer medicinal plants should be explored in detail so that we can come up with potent antioxidants. In the present study ascorbic acid, individual extracts of the three plants used in the study and the combination of these individual extracts were studied for antioxidant activity using reducing power assay. The results showed that even at very low concentrations the individual extracts and their combination demonstrated decent reductive ability in comparison to the standard antioxidant ascorbic acid. Also, the combination of the plant extracts used in the study showed the highest antioxidant potential in the present study when compared to the individual extracts. Thus the extracts of the plants used in the present study and their combination can prove to be good antioxidants if properly formulated and marketed.

\section{REFERENCES}

1. Saxena M, Saxena J, Pradhan A. Flavonoids and phenolic acids as antioxidants in plants and human health. Int J Pharm Sci Rev Res. 2012;16, no 28:130-4.

2. Saxena M, Saxena J, Nema R, Singh D, Gupta A. Phytochemistry of medicinal plants. J Pharmacogn and Phytochem. 2013;1:168-82.

3. Rao N. Bioactive phytochemicals in Indian foods and their potential in health promotion and disease prevention. Asia Pac J Clin Nutr. 2003;12:9-22.

4. Atmani D, Nassima C, Dina A, Meriem B, Nadjet D, Hania B. Flavonoids in human health: From structure to biological activity. Curr Nutr Food Sci. 2009;5:225-37.

5. Kokate CK, Purohit AP, Gokhale SB. Pharmacognosy. Nirali Prakashan, Pune, India. 2010; Vol. I \& II:6.15-6.16.

6. Khandelwal KR. Practical Pharmacognosy:Techniques and Experiments. Nirali Prakashan, Pune, India. 2010;20 th Edition:25.1-25.9.

7. Shah BN, Nayak, BS. Experimental Pharmacognosy. S.Vikas \& Company (Medical Pub. \& Dist.), Jalandhar, India. 2015; Edition 2015:190-200.

8. Oyaizu M. Studies on products of browning reaction: Antioxidative activity of product of browning reaction prepared from glucosamine. Japan J Nutr. 1986;44:307-15.

9. Babu D, Gurumurthy P, Borra SK, Cherian KM. Antioxidant and free radical scavenging activity of triphala determined by using different in vitro models. J Med Plants Res. 2013;39: 2898-905.

10. Sowndhararajan K, Kang SC. Free radical scavenging activity from different extracts of leaves of Bauhinia vahlii Wight \& Arn. Saudi J Biol Sci. 2013;20:319-25. 
11. Pavithra K, Vadivukkarasi S. Evaluation of free radical scavenging activity of various extracts of leaves from Kedrostis foetidissima (Jacq.) Cogn. Food Science and Human Wellness. 2015;4: 42-6.
12. Akanni OO, Owumi SE, Adaramoye OA. In vitro studies to assess the antioxidative, radical scavenging and arginase inhibitory potentials of extracts from Artocarpus altilis, Ficus exasperate and Kigelia Africana. Asian Pac J Trop Biomed. 2014;4:S492-9.

Cite this article: Joshi T, Juyal V. Evaluation of Antioxidant Activity of Some Medicinal plants and their Combination. Pharmacog J $2021 ; 13(2): 596-9$ 